\title{
Social structure and residency in aggregations of male sperm whales
}

\author{
Erland Lettevall, Christoph Richter, Nathalie J aquet, Elizabeth Slooten, \\ Steve Dawson, Hal Whitehead, J enny Christal, and Penelope McCall Howard
}

\begin{abstract}
Sperm whales (Physeter macrocephalus) are sexually dimorphic in several respects, including size, latitudinal distribution, and social structure. Females are known to have complex social structures, including long-term bonds, but the social structures of sexually mature or maturing males have received much less attention. Using data from aggregations of males off Norway, Nova Scotia, New Zealand, and the Galápagos Islands, we examined aggregation size, residence times within aggregations, clustering at the surface, and long-term bonds. Results were generally consistent among study areas. The aggregations found in each area contained around 10-30 males at any time, and were usually a few tens of kilometres across. Mean residence times within aggregations ranged from a few days to a few weeks. Close clustering at the surface was rare, but present at each site. There was no evidence for preferred companionship between individuals at any temporal scale in any of the study areas. The rarity of clustering and the apparent lack of long-term relationships amongst male sperm whales contrast strongly with results of studies on females, suggesting that both close spatial proximity at the surface and permanent bonds between individuals may be a consequence of the need for care of the young.
\end{abstract}

Résumé : Les cachalots (Physeter macrocephalus) présentent un important dimorphisme sexuel, notamment en taille, en distribution latitudinale et en organisation sociale. Les femelles ont une organisation sociale très complexe qui inclut des associations à long terme entre individus, alors que l'organisation sociale des mâles adultes, ou subadultes, reste encore largement inconnue. En utilisant des données provenant de regroupements de mâles au large de la Norvège, de la Nouvelle Écosse, de la Nouvelle Zélande et des Îles Galápagos, nous avons examiné la taille des regroupements, la durée du séjour à l'intérieur de ces regroupement, la manière dont les individus se rassemblent à la surface et les associations à long terme entre individus. Les résultats étaient cohérants d'une région à l'autre. En général, les regroupements avaient quelques dizaines de kilomètres de diamètre et contennaient environ 10-30 mâles. La durée moyenne du séjour à l'intérieur de chacun de ces regroupements allait de quelques jours à quelques semaines. Les individus formaient rarement des groupes compacts de deux ou plusieurs individus séparés par moins de $100 \mathrm{~m}$, mais de tels groupes ont été observés en surface dans chaque région. Rien dans nos données, dans aucune région, ni à aucune des échelles temporelles étudiées, ne laissait croire que certains individus puissent s'associer plus souvent avec tel mâle qu'avec tel autre. Le fait que les individus se regroupaient rarement à la surface et l'absence d'associations à long terme entre mâles présentent un contraste remarquable avec les résultats obtenus chez les femelles. Cela suggère que la proximité spatiale à la surface ainsi que les associations permanentes entre individus servent principalement à assurer les soins aux jeunes.

\section{Introduction}

Social organization ranges from temporary aggregations of interacting individuals at one extreme to more stable groupings of animals with complex social bonds at the other. Female sperm whales (Physeter macrocephalus) are unques-

Received June 11, 2001. Accepted 29 May 2002. Published on the NRC Research Press Web site at http://cjz.nrc.ca on 23 July 2002.

E. Lettevall. ${ }^{1}$ Kristineberg Marine Research Station, Department of Marine Ecology, Göteborg University, SE 45034 Fiskebäckskil, Sweden.

C. Richter, N. Jaquet, E. Slooten, and S. Dawson. Departments of Zoology and Marine Science, University of Otago, P.O. Box 56, Dunedin, New Zealand.

H. Whitehead. Department of Biology, Dalhousie University, Halifax, NS B3H4J1, Canada, and Max Planck Research Center for Ornithology, Andechs, Germany.

J. Christal and P. McCall Howard. Department of Biology, Dalhousie University, Halifax, NS B3H4J1, Canada.

${ }^{1}$ Corresponding author (e-mail: erland.lettevall@kmf.gu.se). tionably social, but among mature males the situation is not so clear (Whitehead and Weilgart 2000). Mature male sperm whales are about 3 times the mass of mature females, and the two sexes spend much of their lives segregated (Best 1979). On a global scale it is notable that females are generally found at latitudes below $40^{\circ}\left(50^{\circ}\right.$ in the North Pacific Ocean), while males can be sighted up to the edge of the pack ice in both hemispheres (Rice 1989). In temperate latitudes there is some overlap between the distribution of groups consisting principally of females and the distribution of aggregations containing only males (Best 1979).

When apart from females, males may be found in aggregations spanning a few kilometres or more. These are sometimes called bachelor groups (Best 1979), but are they actually social? Perhaps male aggregations are a response to external conditions, such as the presence of prey, in which case the location of a particular whale may not be directly related to the presence of others (see Connor 2000). Or perhaps there really are social bonds, as suggested by mass strandings of males (Rice 1989).

The active seeking out of conspecifics would seem to be 
the most fundamental prerequisite for sociality. However, there are many other facets of sociality, an important one being whether animals discriminate among individuals in their associations (Connor 2000). The new permutation methods of Bejder et al. (1998) and Whitehead (1999) allow these possibilities to be tested rigorously and easily. However, to distinguish between preferred companionship and random association among members of an aggregation, we need information about residency within the aggregation, as animals can choose companions only from those in their vicinity.

Until now, social structure within aggregations of males, or bachelor groups, has only been described informally. For instance, Caldwell et al. (1966) observed "loose associations" of young males off California that were "scattered over an area 5 to $10 \mathrm{~km}$ square" and did "not gather into tight schools" but seemed to move fairly cohesively "as a unit". In contrast, "tight schools" of males were reported from both the Azores and New Zealand (Clarke 1956; Gaskin 1970). Best (1979) concluded that large bachelor groups of males spanning 9.4$12.8 \mathrm{~m}$ in body length frequently split up and rejoined over a large area, but was unsure about the constancy of their membership. All these observations were made in the course of whaling, which may well have had an effect on social structure. More recent nonlethal research on sperm whales has begun to illustrate some of the characteristics of the social structure of males. Childerhouse et al. (1995) noted that male sperm whales off Kaikoura were almost invariably found alone (their "groups" were equivalent to the "clusters" of Whitehead and Arnbom (1987), i.e., animals seen within $100 \mathrm{~m}$ of one another coordinating their movements at the surface). From a study on the Scotian Shelf, Canada, Whitehead et al. (1992) found "little apparent social structure" among males. Similarly, within an aggregation of males off the Galápagos Islands, clustering was very rare but the males showed a degree of coordination of heading and the aggregations moved with some cohesion (Christal and Whitehead 1997). Although whaling is less likely to have affected the social structures under observation in these modern studies, exploitation may have long-term consequences for long-lived animals with complex social systems, like sperm whales (Weilgart et al. 1996).

Here we use quantitative methods to examine social structure in male sperm whales at three cool-temperate study sites in Norway, Nova Scotia, and New Zealand, and at the Galápagos Islands near the equator. For each site we examine aggregation sizes, residence times, clustering among males at the surface, and preferred companionship over time.

\section{Methods}

\section{Field studies}

\section{Andenes, Norway}

The occurrence and distribution of sperm whales off Norway are best known from commercial whale-watching from Andenes on Andøya Island (Lettevall et al. ${ }^{2}$ ). During the summer season, whale-watching vessels regularly visit the waters of Bleikdjupet $\left(69^{\circ} 15^{\prime}-70^{\circ} 00^{\prime} \mathrm{N}, 14^{\circ} 50^{\prime}-16^{\circ} 15^{\prime} \mathrm{E}\right)$, a submarine canyon that cuts into the continental shelf about $12.5 \mathrm{~km}$ northwest of Andenes. Data from whaling operations between 1925 and 1971 (summarized by Christensen et al. 1992) and recent sighting surveys (Øien 1990) in the Norwegian Sea highlight this area as a significant habitat for sperm whales, owing to their very high abundance during the summer months. Data were collected between 1987 and 2000 from 18- to 36-m vessels converted from fishing and whaling to whale-watching (Lettevall 2001). In addition, independent sperm whale surveys were carried out from 10- to 12-m auxiliary sailing vessels between 1990 and 1997.

\section{The Gully, Nova Scotia}

Male sperm whales are found in the Gully $\left(43^{\circ} 40^{\prime}-44^{\circ} 15^{\prime} \mathrm{N}\right.$, $\left.58^{\circ} 45^{\prime}-59^{\circ} 25^{\prime} \mathrm{W}\right)$, a prominent submarine canyon on the edge of the Scotian Shelf. These animals were studied during the summer months (June-August) from 1988 to 1998 using 10to $12-\mathrm{m}$ auxiliary sailing vessels, largely as an adjunct to research on northern bottlenose whales (Hyperoodon ampullatus), which also use the canyon (e.g., Whitehead et al. 1997b). The distribution and behavior of Gully sperm whales has been described by Whitehead et al. (1992).

\section{Galápagos Islands, Ecuador}

The Galápagos Islands have been known as a hot spot of sperm whale distribution for over 200 years (Colnett 1798) and were an important whaling area in the 19th century (Shuster 1983). Studies of sperm whales around the islands started in 1985 and are ongoing. Both during the whaling period and during the late 1980s, mainly female sperm whales were found off the Galápagos Islands, with a very few large, probably breeding, males (Hope and Whitehead 1991). However, during the 1990s the females left the islands, and by the end of the decade they were rarely sighted (Whitehead et al. 1997a). In their place were found aggregations of males.

The sperm whales off the Galápagos Islands have been studied using $10-$ to $20-\mathrm{m}$ auxiliary sailing vessels. Here we use only data collected in April-June between 1995 and 1998, when males had become quite common and females increasingly rare. The data were collected within the area $1^{\circ} 20^{\prime} \mathrm{S}-1^{\circ} 0^{\prime} \mathrm{N}, 90^{\circ} 00^{\prime}-92^{\circ} 10^{\prime} \mathrm{W}$. Additional information on the males is presented by Christal and Whitehead (1997) and Christal (1998).

\section{Kaikoura, New Zealand}

Off Kaikoura, male sperm whales are present year-round within a few kilometres of the shore. Their distribution is centered on a submarine canyon just south of the Kaikoura Peninsula $\left(42^{\circ} 27^{\prime}-42^{\circ} 45^{\prime} \mathrm{S}, 173^{\circ} 33^{\prime}-174^{\circ} 0^{\prime} \mathrm{E}\right)$. The $1000 \mathrm{~m}$ depth contour comes to within $5 \mathrm{~km}$ of the shore and whales can usually be found within $20 \mathrm{~km}$. The Kaikoura sperm whales have been studied each austral summer and most winters since 1990 from a 6.6-m rigid-hulled inflatable (Childerhouse et al. 1995).

Groups of females have very occasionally been observed in the Nova Scotia Gully (Whitehead et al. 1992), off Kaikoura, and off the Galápagos Islands (where they were common

\footnotetext{
${ }^{2}$ E. Lettevall, N. Øien, S. Burger, B. Espar Gasset, V. Fleming, T. Sarvas, C. Sellares, and U. Westerberg. Seasonal occurence, resighting rate and body length distribution of male sperm whales (Physeter macrocephalus) off Andenes, Norway. In preparation.
} 
before 1991; Whitehead et al. 1997a), but not off Andenes (Lettevall 1998). However, all encounters involving females have been omitted from the analyses in this paper.

Photographs of the flukes of diving sperm whales were taken with $35-\mathrm{mm}$ cameras with 80 - to $300-\mathrm{mm}$ fixed or zoom lenses and black and white (Galápagos Islands, Nova Scotia) or color (Andenes, Kaikoura) films. Records were kept of cluster sizes of photographed whales. A cluster is defined as a group of animals within $100 \mathrm{~m}$ of one another (200 m for Andenes) that show coordinated movement (Whitehead and Arnbom 1987).

Animals were measured in the Galápagos Islands and Nova Scotia studies using the single-camera photogrammetric method of Gordon (1990) and off Kaikoura by the stereophotogrammetric method of Dawson et al. (1995). Both the single-camera method (Lettevall 1993) and an acoustic method (Wahlberg et al. 1996) were used off Andenes. The acoustic method uses the interpulse interval of sperm whale clicks (Gordon 1991).

\section{What is an aggregation?}

The differences in the nature of these study areas and investigations mean that "aggregation" has rather different operational definitions. Off Andenes, Kaikoura, and Nova Scotia, sperm whale distribution is strongly associated with the deeper waters of a prominent submarine canyon, and in each case aggregations of males are found to be about 10$30 \mathrm{~km}$ across (McCall Howard 1999 ${ }^{3}$; Ciano and Huele 2001; Jaquet et al. 2000). The aggregations may be found in different parts of the three canyons (which span 40-60 km) at any time (e.g., Jaquet et al. 2000; Whitehead et al. 1992). In all three cases there is quantitative evidence that sperm whale densities decrease away from the canyon (Jaquet et al. 2000; Whitehead et al. 1992; Lettevall and $\varnothing_{i e n^{4}}$ ), thus the aggregations are, at least to some extent, geographically bounded. The Galápagos Islands situation is rather different. Discrete aggregations of males a few kilometres across were encountered and tracked acoustically over a much larger study area. Some of these aggregations were fairly stationary, while others moved tens of kilometres over periods of hours or days (Christal and Whitehead 1997; Christal 1998). For instance, the aggregation shown in Fig. 2 of Christal and Whitehead (1997) moved about $50 \mathrm{~km}$ in a northwesterly direction over $17 \mathrm{~h}$.

\section{Photoidentification}

Photographs were matched to identification catalogues for each area following the methods of Arnbom (1987), Dufault and Whitehead (1995), Childerhouse and Dawson (1996), and Lettevall (1998). Only identifications from photographs of a quality greater than or equal to an equivalent of Arnbom's (1987) $Q=3$ are used here.

\section{Aggregation size and residency}

Here we use the "lagged identification rate", $R(\tau)$, where $\tau$ is the lag (see Whitehead 2001), to examine residency within each study area. $R(\tau)$ is the probability that an individual identified in the study area at time $t$ will be reidentified during a subsequent identification of a randomly chosen resident of the study area at time $t+\tau$ later. For any lag $(\tau)$ this can be estimated from the proportion of pairs of reidentifications $\tau$ time units apart:

$$
\text { [1] } \quad R(\tau)=m(\tau) / g(\tau)
$$

where $g(\tau)$ is the number of pairs of identifications made $\tau$ units apart and $m(\tau)$ is the number of these that are from the same individual.

When $\tau$ is short enough that the population is essentially closed, $R(\tau)=1 / N$, where $N$ is the mean number of animals in the study area at a given time. As $\tau$ approaches the mean stay in the study area, $R(\tau)$ begins to fall. Thus, by fitting models to $R(\tau)$ we can estimate both $N$ and the mean residency in the study area (Whitehead 2001). In this application, because we expect associations to decay with time, we fit an exponential model:

$$
R(\tau)=\left(\mu+\mathrm{e}^{-(\mu+1 / q) \tau / q) /(N \mu}+N / q\right)
$$

This corresponds to animals remaining in the study area for a mean of $q$ days at any time and, when outside the study area, returning with probability $\mu$ per day. Only lags of less than 200 days were considered. The model was fitted using likelihood methods as described by Whitehead (2001). For all study areas except the Galápagos Islands, where longer term data were few, this model appeared to provide a reasonable fit to the data (Fig. 1), and the likelihood was little increased by adding terms. Standard errors of the parameters were estimated by means of jackknife techniques in which "pseudo-estimates" were calculated by omitting data from each year in turn (see Efron and Gong 1983). Estimates of $\mu$ were very imprecise and are not presented.

\section{Tests for preferred companionship}

We tested for preferred/avoided companionship among male sperm whales in each study area over similar time periods by first calculating "simple ratio" association indices (see Ginsberg and Young 1992) between all pairs of whales. The studies were divided into periods of 5 days, a time interval considerably shorter than the estimated mean residence times for sperm whales in all areas except the Nova Scotia Gully, where the estimated residence time was quite imprecise because of relatively sparse data. Two analyses were carried out to test for preferred companionship. A pair of whales were considered to be associated if they were either $(i)$ identified within $2 \mathrm{~h}$ of each other (when they would normally have been within about $15 \mathrm{~km}$ of one another) or (ii) identified on the same day (when they would normally have been within about $30 \mathrm{~km}$ of one another).

Using stronger measures of association (such as "in a cluster together") did not affect the outcome of the tests.

The test statistic was the standard deviation of the association indices (Whitehead 1999). Large standard deviations indicate unexpectedly high and (or) low associations between

\footnotetext{
${ }^{3}$ M.P. McCall Howard. 1999. Sperm whales Physeter macrocephalus in the Gully, Nova Scotia: population, distribution, and response to seismic surveying. B.Sc.(Hons.) thesis, Dalhousie University, Halifax, N.S.

${ }^{4}$ E. Lettevall and N. Øien. Movement and aggregation pattern of non-social male sperm whales (Physeter macrocephalus) at the "Bleik Canyon" of the Norwegian Sea. In preparation.
} 
Fig. 1. Lagged identification rates for sperm whales, Physeter macrocephalus (continuous line), in the four study areas (with a moving average of 100 points; 200 points for the Galápagos Islands), together with fitted models (broken line), using eq. 2.
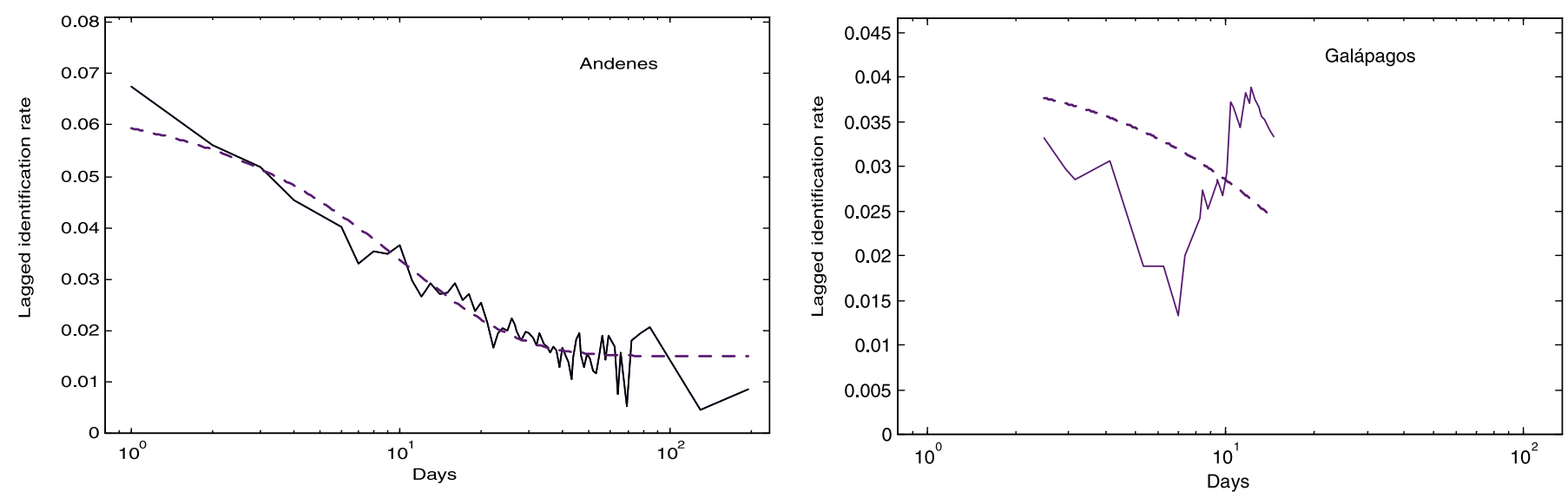

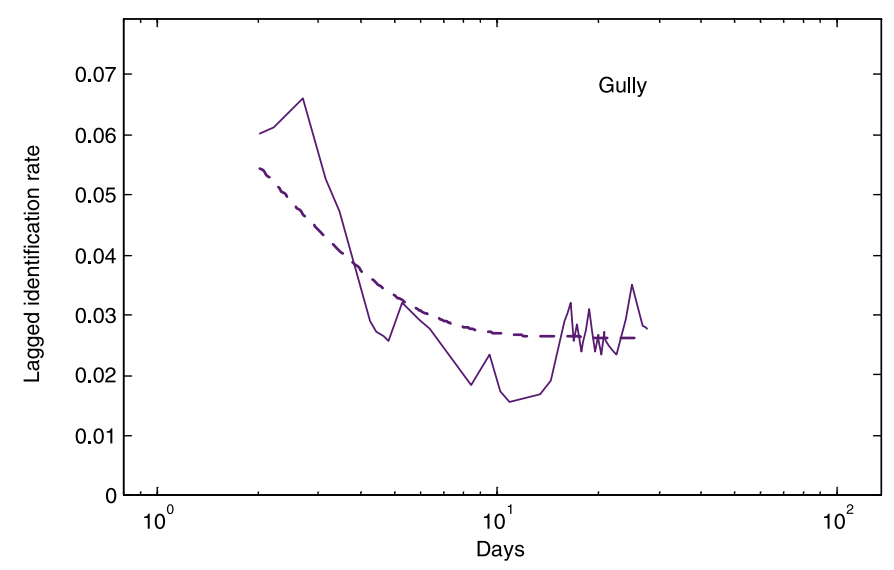

some pairs, and so indicate preferred or avoided companions. The expected distribution of the standard deviations was calculated using the permutation method of Bejder et al. (1998) with an extension described by Whitehead (1999). Associations among whales identified during any 5-day sampling period were randomly permuted in such a way that each whale had the same number of associates as in the real data. Because the permutations using Bejder et al.'s (1998) method are not independent, more permutations than normal are required. We carried out sufficient permutations to stabilize the $p$ values (within $1 \%$, or so that they were clearly not significant at $p<0.05$ ). A $p$ value for any set of randomizations is the proportion of random datasets in which the standard deviation of the association indices is greater than that of the real data (see Bejder et al. 1998).

\section{Results}

Aggregations contained about 10-24 male sperm whales at any given time (Table 1). Field observation and length estimates indicated that the great majority of these animals were sexually mature or maturing males (for information on sexual maturity in male sperm whales see Best et al. 1984), and similar in size to the males observed interacting with groups of females off the Galápagos Islands (Whitehead

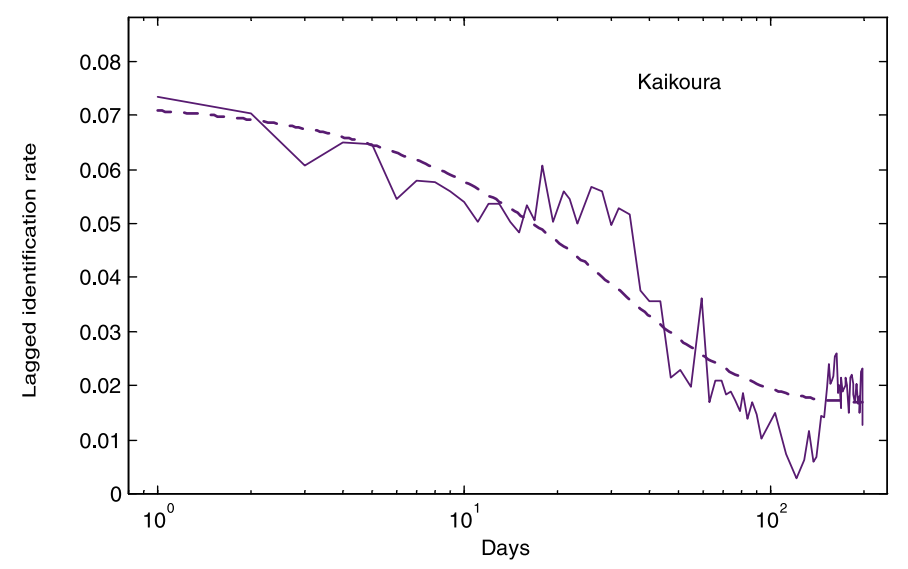

1993). However, animals were generally larger, and presumably older, at the high latitude of Andenes than at the other three sites (Table 1). Animals spent 3-42 days in each study area (Fig. 1), showing great individual variation, with a few animals apparently resident for several weeks or more (e.g., Childerhouse et al. 1995).

Although animals were usually seen alone, pairs (clusters containing 2 animals) were sometimes sighted, and clusters containing up to 6 animals were observed off Andenes, with up to 5 animals off Kaikoura (Fig. 2, Table 2). These individuals were occasionally observed to be as close to each other as those off Kaikoura and Andenes, but nearest neighbor distances were of the order of one body length, as in clusters of females. The average number of individuals seen together was about 1.1 for all study areas. Because the data were from photoidentifications, this also represents the "typical" cluster size experienced by a randomly chosen member of the population. The mean typical cluster size is always greater than or equal to the mean cluster size experienced by an observer because there are more animals in larger clusters, so, when calculating typical cluster size, a cluster of 6 is counted 6 times, whereas a cluster of 2 is only counted twice (Jarman 1974).

Repeated resightings of 2 photoidentified individuals together are rare. Off the Galápagos Islands there was one 


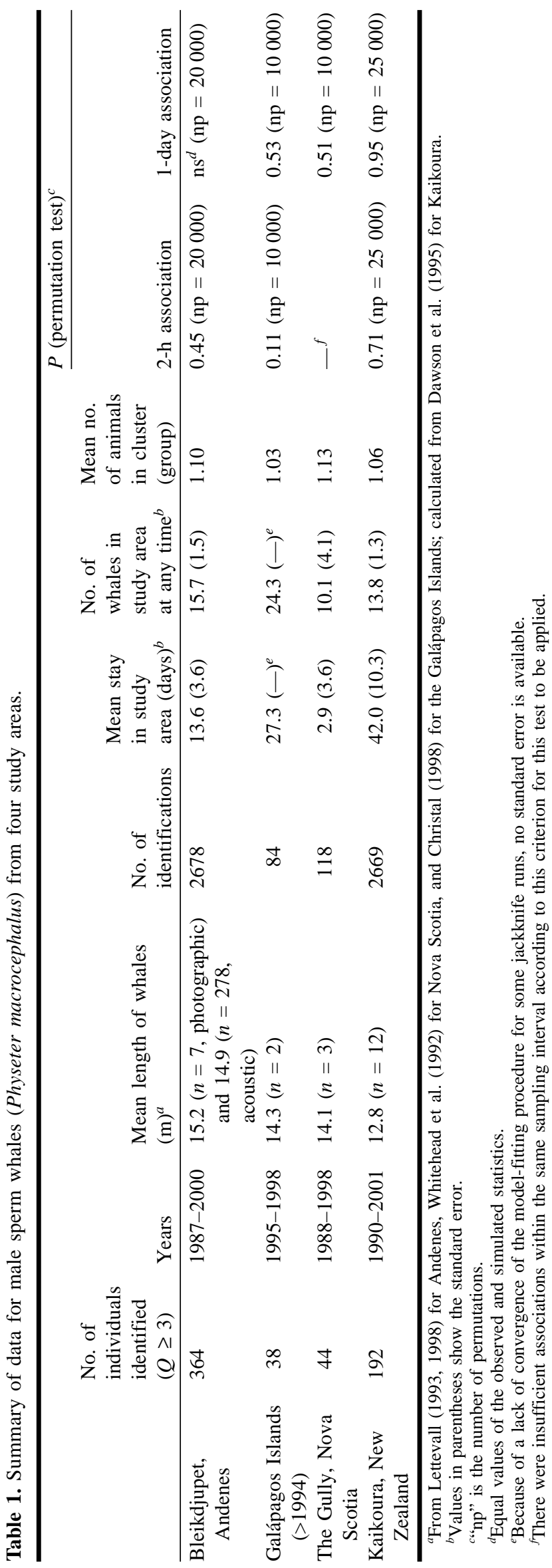

instance of a pair (Nos. 570 and 572) clustered on two consecutive surfacings (Christal 1998). From Kaikoura and Andenes there are more data. Off Kaikoura, one pair (NN 80 and HL 120) were photoidentified clustered on two consecutive surfacings as well as during a single surfacing 3 days later (14:12 and 15:05 on 7 December 1996 and on 17 December 1996). Another pair (HL 210 and HL 180) were photographed clustered twice on the same day separated by over an hour (10:05 and 12:20 on 13 February 1999). Off Andenes, a pair (Nos. 273 and 293) were photoidentified clustered on three consecutive surfacings (11:43, 12:08, and 12:44 on 16 August 1997), and on another occasion there were visual observations of consistent clustering of 2 identifiable individuals within a day.

Relaxing the definition of association to "identified within $2 \mathrm{~h}$ " or "identified within 1 day" increased the number of repeat associations, but some apparent preferred companionships could simply have resulted from random companionship within a small population. For instance, 2 individual whales were identified within 25 min of each other on both 14 and 16 July 1988 in the Nova Scotia Gully. Does this indicate preferred companionship, or was it just by chance that we saw them "together" the second time? To test this, we used Bejder et al.'s (1998) permutation tests for preferred and (or) avoided companions. For none of the datasets was there statistically significant evidence that associations among members of the aggregation were other than random (Table 1).

\section{Discussion}

Our quantitative analysis confirms some of the statements made in previous papers about male sperm whales (e.g., Caldwell et al. 1966; Gaskin 1970; Best 1979; Whitehead et al. 1992; Childerhouse et al. 1995; Christal and Whitehead 1997). In our four study areas, aggregations (or bachelor groups) were small, containing around 10-30 animals at any time, and were usually spread out over several kilometres of ocean, clustering being rare, though present, at each site. Mean residence times within aggregations were generally a few days to a few weeks. This is generally consistent with the analyses of residency at Kaikoura by Childerhouse et al. (1995) and Jaquet et al. (2000). The results of these studies indicate a dichotomy between "residents", who spend weeks at a time in the Kaikoura canyon, and "transients", who briefly pass through. Such differences may also be present in the other study areas (e.g., McCall Howard 1999; Ciano and Huele 2001).

Our principal new result, the lack of evidence for preferred companionship at any temporal scale in any of the study areas, suggests that if this is the acid test of sociality, male sperm whales may not, in this sense, be social. However, they clearly do on occasion seek each other out to form clusters (Table 2), they coordinate their headings within aggregations (Christal and Whitehead 1997), and, perhaps most tellingly, on occasion they strand together (Rice 1989). In a revealing observation made on Sable Island, Nova Scotia, in 1997, a male sperm whale was observed to strand intentionally within $50 \mathrm{~m}$ of 2 other, previously stranded whales, even though $25 \mathrm{~km}$ of apparently featureless beach was available (Lucas and Hooker 2000). Thus, adult male sperm whales, when not involved in breeding, do react to each other's pres- 
Table 2. Distributions of cluster sizes.

\begin{tabular}{lcccc}
\hline & \multicolumn{5}{c}{$\begin{array}{l}\text { Galápagos } \\
\text { Islands } \\
\text { Cluster size }\end{array}$} & Andenes & $\begin{array}{l}\text { The Gully, } \\
(>1992)\end{array}$ & Nova Scotia & Kaikoura \\
\hline 1 & 2515 & 29 & 83 & 2416 \\
2 & 107 & 1 & 12 & 104 \\
3 & 29 & 0 & 3 & 13 \\
4 & 4 & 0 & 0 & 5 \\
5 & 2 & 0 & 0 & 4 \\
6 & 4 & 0 & 0 & 0 \\
Total & 2661 & 30 & 96 & 2542 \\
Mean cluster size & 1.08 & 1.03 & 1.18 & 1.06 \\
\hline
\end{tabular}

Note: Mean cluster sizes were as follows: 1.08 for Andenes, 1.03 for the Galápagos Islands, 1.18 for the Gully, and 1.06 for Kaikoura.

ence, even though they appear not to have long-term preferred associates.

Despite the consistency of the results among our study areas, they still may not be representative of the social structures of all male aggregations. For instance, the largest ( 5-15 animals) bachelor groups reported by Gaskin (1970) contained generally smaller animals $(\sim 12-14 \mathrm{~m})$ than the aggregations of nonbreeding males studied off Andenes, off the Galápagos Islands, and in the Nova Scotia Gully (but not those in Kaikoura), and were observed in deeper, more open waters. Off South Africa, Best (1999) found that mediumsized and large males seemed to prefer waters closer to the continental shelf, while females tended to occur mainly in water deeper than $1000 \mathrm{~m}$. Best (1979) also describes schools of 1-50 small bachelors containing animals from 9.4 to $12.8 \mathrm{~m}$ long, and notes that there seemed to be a tendency for the groups to contain 12-15 whales or multiples thereof. Thus, it is possible that more structured bachelor groups of smaller males do exist, perhaps especially away from the continental shelf edges, where males not involved in breeding have principally been studied.

The general pattern of male sociality uncovered here, and suggested in previous papers (Caldwell et al. 1966; Gaskin 1970; Best 1979; Whitehead et al. 1992; Childerhouse et al. 1995; Christal and Whitehead 1997), contrasts dramatically with the very pronounced, and likely very important, social structures of female sperm whales summarized in Table 3.

That both sexes are found in aggregations suggests that these are formed in response to some factor which is significant to both males and females, of which food is the most likely (Whitehead and Weilgart 2000). However, compared with those of females, aggregations of nonbreeding males tend to be more dispersed and yet more geographically stable (Table 3). These contrasts may result from the more predictable distribution of food in underwater canyons, habitats that are highly structured physically and feature in three of our four study areas. Females have been studied only in more open habitats (e.g., Galápagos Islands, Azores).

In contrast to what is seen in females, there is little evidence for structured groups among males over smaller scales (tens of kilometres) and none for permanent social units. The most obvious sign of this is that it is rare for 2 individuals to be repeatedly seen together (Table 3 ). The extended periods spent at the surface during which females seem to
Fig. 2. Cluster of 2 males surfacing off Andenes (photograph by Hvalsafari, Andenes).

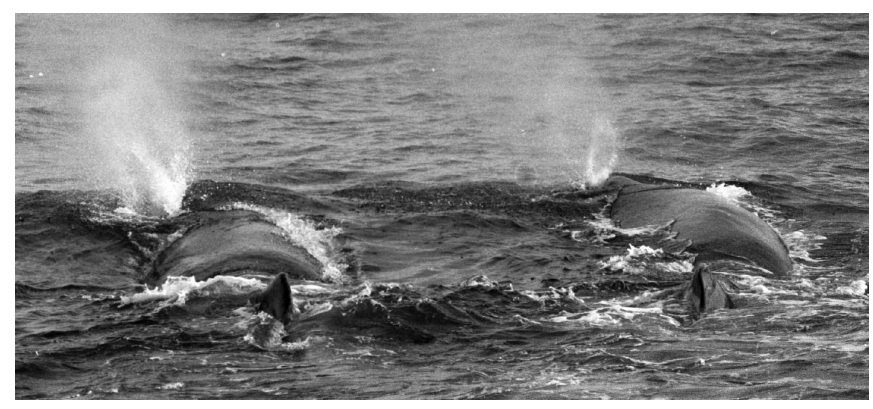

socialize (Whitehead and Weilgart 1991) are also exceptionally rare among these males (Whitehead et al. 1992; Jaquet et al. 2000).

Together these results suggest that the highly social females form structured groups, i.e., permanent units and clusters, for reasons that are not important, or not nearly as important, to the males. The most obvious of these might be protection of their young against predators. It seems very likely that the need for care of calves has been a driving factor in the evolution of sociality in female sperm whales (Best 1979; Gordon 1987; Whitehead 1996; also for muskox, Ovibos moschatus, see Klein 1999).

The loose, apparently unstructured, relationships among nonbreeding males are similar to those of many aquatic organisms that provide little or no care for their young. Many aggregations of seabirds and pinnipeds at sea seem comparable (e.g., Wells et al. 1999). However, the contrast between the social systems of the sexes is most remarkable for sperm whales, indicating an unusual evolutionary trajectory for female sociality in this species (Weilgart et al. 1996). Also remarkable is the way in which young males, who seem to take a full role in the affiliative and cooperative behavior that occurs within their mother's social unit for several years (e.g., Gordon 1987), appear to drop such behavior from their repertoire after dispersal. Such contrasts and transitions give useful insights into the evolution of sociality.

There are similar situations among animals on land. In red deer (Cervus elephas), for instance, stag groups were looser, less permanent, and less defined than those of hinds (CluttonBrock et al. 1982). But the most obvious parallel is with elephants (Elephantidae), whose social systems are remarkably similar to those of sperm whales (Weilgart et al. 1996). Female elephants show several levels of social organization, including parallels with all the elements listed in Table 3, whereas nonbreeding males, after dispersal from their natal group, are found in small groups with very labile membership (Douglas-Hamilton et al. 2001). However, new research on African elephants (Loxodonta africana) suggests that, despite the appearance of randomness in male-male associations, short-term, but strong, associations between particular pairs may be repeated many times despite long intervening separations (Douglas-Hamilton et al. 2001). It is certainly possible, and not inconsistent with our data, that a similar cryptic social structure exists among male sperm whales, and will be revealed as studies become longer, more detailed, and more sophisticated. 
Table 3. Social structures of nonbreeding sexually mature male sperm whales compared with those of females (data for females are from Whitehead and Weilgart 2000).

\begin{tabular}{|c|c|c|}
\hline Structure & Females & Nonbreeding mature males \\
\hline Aggregation & $\begin{array}{l}\sim \text { Tens of animals aggregated over an area } \sim 10 \mathrm{~km} \text { across for } \\
\text { a few hours }\end{array}$ & $\begin{array}{l}\sim 20 \text { males aggregated over an area } \sim 20 \mathrm{~km} \text { across for } \\
\text { days or longer }\end{array}$ \\
\hline Group & $\begin{array}{l}\sim 20 \text { animals foraging in structured formations spanning } \sim 1 \mathrm{~km} \\
\text { for days }\end{array}$ & $\begin{array}{l}\text { Little evidence for groups, except coordinated heading } \\
\text { by aggregated males }\end{array}$ \\
\hline Social unit & $\begin{array}{l}\text { Tens of animals with long-term relationships lasting years to } \\
\text { decades; may contain several matrilines }\end{array}$ & No evidence for long-term relationships \\
\hline
\end{tabular}

\section{Acknowledgements}

We thank the many people who collected data at sea and assisted ashore. The research off Andenes was funded initially by the World Wide Fund for Nature (WWF) Sweden, Denmark, and Norway and later by Göteborg University, Hvalsafari Ltd., the Nordic Academy for Advanced Studies, the Whale and Dolphin Conservation Society (WDCS), and the Royal Swedish Academy of Science. The Nova Scotia study was funded by the Natural Sciences and Engineering Research Council of Canada (NSERC), WDCS, the Endangered Species Recovery Fund of WWF Canada and Environment Canada, and the Canadian Federation of Humane Societies. The Galápagos Islands study was funded by NSERC and WDCS. Funding for research at Kaikoura was provided initially by WWF New Zealand and Telecom N.Z. Ltd. and latterly by the University of Otago and the New Zealand Department of Conservation. Reckitt and Colman (N.Z.) Ltd., Ocean Electronics, and Hutchwilco assisted by sponsoring items of equipment. The research was carried out under a permit from the N.Z. Department of Conservation. The research off Nova Scotia was performed under permits from Fisheries and Oceans Canada. The Andenes research would have been impossible without collaboration between all the whale-watching guides and research assistants, as well as the crews of the whale-watching vessels. We especially thank Stefan Burger, Jacki Ciano, Vivi Fleming, Bo Johanneson, Morten Lindhard, Tuula Sarvas, Cris Sellares, Hanne Strager, Fernando Ugarte, and Ulrika Westerberg. The Galápagos Islands study was carried out with the assistance and collaboration of the Armada of Ecuador, the Charles Darwin Station, the Galápagos National Park Service, the Instituto Nacional de Pesca, and Godfrey Merlen. The manuscript was improved by review from Graham Timmins, Peter Best, and an anonymous reviewer.

\section{References}

Arnbom, T. 1987. Individual identification of sperm whales. Rep. Int. Whal. Comm. No. 37. pp. 201-204.

Bejder, L., Fletcher, D., and Bräger, S. 1998. A method for testing association patterns of social animals. Anim. Behav. 56: 719725.

Best, P.B. 1979. Social organization in sperm whales, Physeter macrocephalus. In Behavior of marine animals. Vol. 3. Edited by H.E. Winn and B.L. Olla. Plenum Press, New York. pp. 227289.

Best, P.B. 1999. Food and feeding of sperm whales Physeter macrocephalus off the west coast of South Africa. S. Afr. J. Mar. Sci. 21: 393-413.

Best, P.B., Canham, P.A.S., and Macleod, N. 1984. Patterns of reproduction in sperm whales, Physeter macrocephalus. Rep. Int. Whaling Comm. Spec. Issue No. 6. pp. 51-79.

Caldwell, D.K., Caldwell, M.C., and Rice, D.W. 1966. Behavior of the sperm whale Physeter catodon L. In Whales, dolphins and porpoises. Edited by K.S. Norris. University of California Press, Berkeley. pp. 677-717.

Childerhouse, S.J., and Dawson, S.M. 1996. Stability of fluke marks used in individual photoidentification of sperm whales at Kaikoura, New Zealand. Mar. Mamm. Sci. 12: 447-451.

Childerhouse, S.J., Dawson, S.M., and Slooten, E. 1995. Abundance and seasonal residence of sperm whales at Kaikoura, New Zealand. Can. J. Zool. 73: 723-731.

Christal, J. 1998. An analysis of sperm whale social structure: patterns of association and genetic relatedness. Ph.D. dissertation, Dalhousie University, Halifax, N.S.

Christal, J., and Whitehead, H. 1997. Aggregations of mature male sperm whales on the Galápagos Islands breeding ground. Mar. Mamm. Sci. 13: 59-69.

Christensen, I., Haug, T., and Øien, N. 1992. Seasonal distribution, exploitation and present abundance of stocks of large baleen whales (Mysticeti) and sperm whales (Physeter macrocephalus) in Norwegian and adjacent waters. ICES J. Mar. Sci. 49: 341-355.

Ciano, J.N., and Huele, R. 2001. Photoidentification of sperm whales at Bleik Canyon, Norway. Mar. Mamm. Sci. 17: 175-180.

Clarke, R. 1956. Sperm whales of the Azores. Discovery Rep. 28: 237-298.

Clutton-Brock, T.H., Guinness, F.E., and Albon, S.D. 1982. Red deer: behavior and ecology of two sexes. University of Chicago Press, Chicago.

Colnett, J. 1798. A voyage to the South Atlantic and round Cape Horn into the Pacific Ocean, for the purpose of extending the spermaceti whale fisheries. W. Bennett, London.

Connor, R.C. 2000. Group living in whales and dolphins. In Cetacean societies. Edited by J. Mann, R.C. Connor, P.L. Tyack, and H. Whitehead. University of Chicago Press, Chicago. pp. 199218.

Dawson, S.M., Chessum, C.J., Hunt, P.J., and Slooten, E. 1995. An inexpensive, stereographic technique to measure sperm whales from small boats. Rep. Int. Whaling Comm. No. 45. pp. 431436.

Douglas-Hamilton, I., Barnes, R.F.W., Shoshani, H., Williams, A.C., and Johnsingh, A.J.T. 2001. Elephants. In The new encyclopedia of mammals. Edited by D. Macdonald. Oxford University Press, Oxford.

Dufault, S., and Whitehead, H. 1995. An assessment of changes with time in the marking patterns used for photo-identification 
of individual sperm whales, Physeter macrocephalus. Mar. Sci. (N.Y.), 11: 335-343.

Efron, B., and Gong, G. 1983. A leisurely look at the bootstrap, the jackknife, and cross-validation. Am. Stat. 37: 36-48.

Gaskin, D.E. 1970. Composition of schools of sperm whales Physeter catodon Linn. east of New Zealand. N.Z. J. Mar. Freshw. Res. 4: 456-471.

Ginsberg, J.R., and Young, T.P. 1992. Measuring association between individuals or groups in behavioural studies. Anim. Behav. 44: 377-379.

Gordon, J.C.D. 1987. Sperm whale groups and social behaviour observed off Sri Lanka. Rep. Int. Whaling Comm. No. 37. pp. 205217.

Gordon, J.C.D. 1990. A simple photographic technique for measuring the length of whales from boats at sea. Rep. Int. Whaling Comm. No. 40. pp. 581-588.

Gordon, J.C.D. 1991. Evaluation of a method for determining the length of sperm whales (Physeter macrocephalus) from their vocalizations. J. Zool. (Lond.), 224: 301-314.

Hope, P.L., and Whitehead, H. 1991. Sperm whales off the Galápagos Islands from 1830-50 and comparisons with modern studies. Rep. Int. Whaling Comm. No. 41. pp. 273-286.

Jaquet, N., Dawson, S., and Slooten, E. 2000. Seasonal distribution and diving behaviour of male sperm whales off Kaikoura: foraging implications. Can. J. Zool. 78: 407-419.

Jarman, P.J. 1974. The social organization of antelope in relation to their ecology. Behaviour, 48: 215-267.

Klein, D.R. 1999. Comparative social learning among arctic herbivores: the caribou, muskox and arctic hare. Symp. Zool. Soc. Lond. No. 72. pp. 126-140.

Lettevall, E. 1993. Estimating the length of sperm whales (Physeter macrocephalus) off northern Norway using a photo-telemetric technique. Master's thesis, Göteborg University, Göteborg, Sweden.

Lettevall, E. 1998. Sperm whales: social behaviour, mating seasonality and photo-identification. Thesis for Licentiate in Philosophy examination, Göteborg University, Göteborg, Sweden.

Lettevall, E. 2001. The ID-catalogue of sperm whales identified off Andenes, Norway. Version 2.1. Available at http://www.tmbl.gu.se/ physeter/physeter.html (accessed on 23 July 2001).

Lucas, Z.N., and Hooker, S.K. 2000. Cetacean strandings on Sable Island, Nova Scotia, 1970-1998. Can. Field-Nat. 114: 45-61.

Øien, N. 1990. Sightings surveys in the northeast Atlantic in July 1988: distribution and abundance of cetaceans. Rep. Int. Whaling Comm. No. 40. pp. 499-511.

Rice, D.W. 1989. Sperm whale. Physeter macrocephalus Linnaeus,
1758. In Handbook of marine mammals. Vol. 4. Edited by S.H. Ridgway and R. Harrison. Academic Press, London. pp. 177-233.

Shuster, G.W. 1983. The Galápagos Islands: a preliminary study of the effects of sperm whaling on a specific whaling ground. Rep. Int. Whaling Comm. Spec. Issue No. 5. pp. 81-82.

Wahlberg, M., Lettevall, E., and Medlund, L. 1996. Estimating the length of sperm whales from inter-pulse intervals in the clicks. In European Research on Cetaceans-8: Proceeding of the 9th Annual Conference of the European Cetacean Society, Lugano, Switzerland, 9-12 February 1995. Edited by P.G.H. Evans. The Eyropean Cetacean Society. pp. 38-40.

Weilgart, L., Whitehead, H., and Payne, K. 1996. A colossal convergence. Am. Sci. 84: 278-287.

Wells, R.S., Boness, D.J., and Rathbun, G.B. 1999. Behavior. In Biology of marine mammals. Edited by J.E. Reynolds and S.A. Rommel. Smithsonian Institution Press, Washington, D.C. pp. 324 422.

Whitehead, H. 1993. The behaviour of mature male sperm whales on the Galapagos breeding grounds. Can. J. Zool. 71: 689-699.

Whitehead, H. 1996. Babysitting, dive synchrony, and indications of alloparental care in sperm whales. Behav. Ecol. Sociobiol. 38: 237-244.

Whitehead, H. 1999. Testing association patterns of social animals. Anim. Behav. 57: F26-F29.

Whitehead, H. 2001. Analysis of animal movement using opportunistic individual-identifications: application to sperm whales. Ecology, 82: 1417-1432.

Whitehead, H., and Arnbom, T. 1987. Social organization of sperm whales off the Galápagos Islands, February-April 1985. Can. J. Zool. 65: 913-919.

Whitehead, H., and Weilgart, L. 1991. Patterns of visually observable behaviour and vocalizations in groups of female sperm whales. Behaviour, 118: 275-296.

Whitehead, H., and Weilgart, L. 2000. The sperm whale: social females and roving males. In Cetacean societies. Edited by J. Mann, R.C. Connor, P. Tyack, and H. Whitehead. University of Chicago Press, Chicago. pp. 154-172.

Whitehead, H., Brennan, S., and Grover, D. 1992. Distribution and behaviour of male sperm whales on the Scotian Shelf, Canada. Can. J. Zool. 70: 912-918.

Whitehead, H., Christal, J., and Dufault, S. 1997a. Past and distant whaling and the rapid decline of sperm whales off the Galápagos Islands. Conserv. Biol. 11: 1387-1396.

Whitehead, H., Gowans, S., Faucher, A., and McCarrey, S. $1997 b$. Population of northern bottlenose whales in the Gully, Nova Scotia. Mar. Mamm. Sci. 13: 173-185. 